\title{
Research priorities for tobacco control in developing countries: a regional approach to a global consultative process
}

Enis Baris, Linda Waverley Brigden, Joanne Prindiville, Vera Luiza da Costa e Silva, Hatai Chitanondh, Stephen Chandiwana

Research for

International Tobacco

Control, International

Development Research

Centre, Ottawa,

Ontario, Canada

E Baris

L Waverley Brigden

J Prindiville

Tobacco Control and

Primary Cancer

Prevention

Coordination-Contapp,

National Cancer

Institute (INCA),

Ministry of Health,

Rua des Invalidos,

212/2 andar, Rio de

Janeiro, Brazil

V L da Costa e Silva

Thailand Health

Promotion Institute,

The Regent Royal

Place 1, Room 2/64,

2220 Soi Mahadlek

Luang 1, Rajdamri

Road, Bangkok 10330,

Thailand

H Chitanondh

Blair Research

Institute, Josiah

Tongogara/Mazowe

Street, PO Box 8105,

Causeway, Harare,

Zimbabwe

S Chandiwana

Correspondence to: Linda Waverley Brigden,

Executive Director, Research

for International Tobacco

Control, International

Development Research

Centre, PO Box 8500 ,

Ottawa, Ontario K1G $3 \mathrm{H} 9$,

Canada; e-mail:

lbrigden@idrc.ca

Received 2 August 1999 and in revised form

15 February 2000.

Accepted 16 February 2000

\begin{abstract}
Objective-To develop regional tobacco control research agendas for developing countries through a consultative process. Methods-Research for International Tobacco Control, located at the International Development Research Centre in Ottawa, Canada, convened three regional meetings for Latin America and the Caribbean, South and Southeast Asia, and Eastern, Central and Southern Africa. Participation by researchers, policymakers, and advocates from a wide range of disciplines ensured an accurate representation of regional issues.
\end{abstract}

Results-The four main recurring themes within each regional agenda were: (1) the lack of standardised and comparable data; (2) the absence of a network for communication of information, data, and best practices; (3) a lack of adequate capacity for tobacco control research, especially in non-health related areas such as economics and policy analysis; and (4) a need for concerted mobilisation of human and financial resources in order to implement a comprehensive research agenda, build partnerships, and stimulate comparative research and analysis. Specific research issues included the need for descriptive data with respect to the supply side of the tobacco equation, and analytical data related to tobacco use, production and marketing, and taxation.

Conclusions-There was a uniform perception of tobacco as a multidisciplinary issue. All regional agendas included a balance of health, economic, agricultural, environmental, sociocultural, and international trade concerns. Research data are urgently required to provide a sound basis for the development of tobacco control policies and programmes. As tobacco control takes its rightful place on the global health agenda, it is vital that funding for tobacco control research be increased.

(Tobacco Control 2000;9:217-223)

Keywords: regional tobacco control programmes; developing countries; tobacco control research
Tobacco use continues to be the leading preventable cause of death and disability among adults in the world today. By the year 2020, tobacco use is expected to cause approximately 8.4 million deaths, $70 \%$ of these in developing countries. ${ }^{1}$ Aggressive marketing by transnational tobacco companies (TTCs) to expand their markets has resulted in increasing rates of tobacco consumption in the south. Furthermore, changing social norms in developing countries have made women an additional potential market for tobacco. ${ }^{2}$ During 1974-76, $49 \%$ of the world's tobacco consumption was in developing countries; by $1984-86$ this had risen to $61 \%$. In the year 2000, developing countries are expected to account for $71 \%$ of global tobacco consumption. $^{3}$

Tobacco use is more than a health hazard; it is a quintessential challenge to sustainable development, with consequences for the environment, trade, taxation, social policy, direct and indirect health care costs, and power/gender/labour relations, both at the societal and household levels. Moreover, all of these dimensions apply equally to both the production and consumption of tobacco and its products. At present, close to $70 \%$ of the world's tobacco is grown in the developing countries, yet tobacco farmers receive only a small percentage of the profits that tobacco production generates. ${ }^{3}$ Moreover, this nonessential, non-food crop depletes soil nutrients faster than most other crops and requires heavy use of fertilizers and pesticides, the environmental costs of which are borne primarily by the farming communities. Curing tobacco consumes an estimated 200000 hectares of woodland each year, mainly in the developing world, amounting to $1.7 \%$ of global net loss of forest cover. ${ }^{4}$ It is a major occupational hazard, especially for women and children who do the menial work on the plantations and in the smoke-houses. ${ }^{5}$

Many governments in the south are hesitant to curtail tobacco production and lukewarm toward controlling tobacco use, as they enjoy significant revenues from excise taxes on cigarettes and the export of tobacco leaf. Also they lack data to substantiate the magnitude of the tobacco epidemic and the effectiveness of interventions. However, comprehensive 
tobacco control policies based on sound research have been shown to be effective in reducing tobacco use in both developed and developing countries, bringing about unprecedented health benefits without harming economies. ${ }^{6}$

In Canada, the annual per capita (age 15+ years) consumption of cigarettes (including roll-your-own) was $40 \%$ lower in 1992 than in 1982, due mainly to the implementation of a comprehensive package of tobacco control interventions. ${ }^{7}$ Similarly, as reported in a study supported by Research for International Tobacco Control (RITC), tobacco control measures introduced in South Africa since 1990 caused cigarette consumption to decline by an average of $11 \%$ per annum during 199195 , and by nearly $20 \%$ between the end of 1996 and the end of $1997 .^{8}$ In Thailand ${ }^{9}$ and Taiwan, ${ }^{10}$ implementation of World Health Organization (WHO) recommendations for comprehensive tobacco control strategies offset, at least partially, the impact of market opening on overall cigarette consumption.

Global expenditures on tobacco control research, which forms the basis for sound tobacco control policies and programmes, are modest in spite of the significant burden of tobacco related disease. In 1990, it was estimated that approximately US\$148-164 million were allocated to global tobacco control research and development. This represented an expenditure of only $\$ 4.31$ per disability adjusted life year lost. ${ }^{11}$ Moreover, even though tobacco production and consumption entail extensive environmental and societal costs, the majority of global funding is directed toward health related research rather than multidisciplinary, policy oriented tobacco control research. Furthermore, this research takes place predominantly in developed countries and is only partially relevant to the socioeconomic and political climate in many developing countries.

Limited resources, competing priorities, and lack of awareness on the part of policymakers and donor agencies limit the financial resources available to those doing tobacco control research in a developing country setting. Circumscribed capacity to undertake multidisciplinary policy research limits both the quality and quantity of such studies. It is crucial, therefore, to develop a truly global research agenda that will help both the development and research communities to identify the most pressing research issues and to build research capacity to address these constraints in countries of greatest need.

RITC, formerly the International Tobacco Initiative, was established to assure the existence of a strong research, funding, analysis and knowledge base for the development of effective public policies for tobacco control to support sustainable and equitable development. Based at the International Development Research Centre (IDRC) in Ottawa, Canada, RITC was established as IDRC's response to the invitation made at the 1995 Bellagio conference by a group of 22 international agencies and experts to take the lead in devel- oping tobacco control research strategies and global partnerships. Since then, RITC has been encouraging new and efficient linkages between individuals and organisations working on tobacco control research and has fostered north-south and south-south collaboration.

RITC has initiated a bottom up, proactive process to establish regional tobacco control research agendas. Several attempts have been made in the past to outline priorities for tobacco control research, such as the Report of a working group convened during the 10th World Conference on Tobacco or Health. ${ }^{12}$ However, RITC's process was unique in that it was broad based and multidisciplinary, including participants from a wide range of developing countries within each region. Their participation served to ensure that the ensuing research agenda truly represented regional concerns and identified locally acceptable ways and means of putting that agenda into action effectively. The integration of these agendas has the potential to constitute a sound basis for a global tobacco control research agenda.

\section{Methods}

Between August 1998 and January 1999, RITC convened three meetings to initiate the formulation of regional tobacco control research agendas for Latin America and the Caribbean, South and Southeast Asia, and Eastern, Central and Southern Africa, respectively. Each regional meeting involved experts who were knowledgeable about tobacco control issues at the country level and represented a broad range of disciplines. Efforts were made to achieve a mixture of $50 \%$ researchers, $30 \%$ policymakers, and $20 \%$ advocates at each meeting. While a blend of all three interest groups was achieved in the Latin American and African meetings, participants at the Asian meeting were predominantly researchers or practitioners.

Delegates were encouraged to consider issues related to tobacco in a multidisciplinary manner and to think on a national, regional, and global scale. They were asked to discuss not only problems associated with tobacco, but also the determinants of those problems and the availability of effective interventions.

\section{Results}

COMMON PREOCCUPATIONS

Research themes were consistent across all three regions, with small variations that may reflect the make up of individual discussion groups and/or emerging issues in specific regions. Throughout all discussions, participants focused on tobacco as a multidisciplinary issue, considering both the production and consumption aspects of the equation. The cultivation of tobacco, its importance as a form of employment, historical and cultural uses of tobacco, trade implications, marketing strategies, changing societal norms, and environmental issues were seen as an integral part of the tobacco issue. Participants at all three workshops repeatedly came back to the following research priorities: 
(1) The lack of standardised and comparable dataThe most recurrent theme at all three meetings was the need for regional surveillance systems and research to provide baseline data on: the prevalence of tobacco use; consumption patterns and trends; patterns of and trends in tobacco-attributable morbidity and mortality; existing policies and programmes; and ongoing and completed research initiatives. While a certain amount of material exists, databases of this nature are costly to maintain. What is especially needed is detailed information broken down by sex, age group, populations at risk, and regions and provinces.

(2) The absence of a network for communication of information, data, and best practices-While many of the electronic networks have contributed positively to the discussion of tobacco control, they are not universally accessible in the developing world. The absence of a network was perceived as a major impediment to collaboration and partnership in all regions. Consistent with this was a desire by all regions to conduct a mapping exercise to identify: the current stakeholders in tobacco control initiatives; research institutes and researchers currently involved in tobacco control; and the needs and activities of the whole tobacco control community-including researchers, advocates and policymakers - so as to harmonise efforts and mechanisms of control.

(3) Lack of adequate capacity for tobacco control research, especially in non-health related areas such as economics and policy analysis-The current and potential socioeconomic burden of tobacco production and consumption underscores the need to bolster research capacity in developing countries. A scarcity of skills and competence for multidisciplinary and policy research is compounded by the failure of donor agencies to be proactive in funding research on evolving issues.
Table 1 Specific research issues

- The chain of tobacco production from farmer to retailer - Cultivation and manufacturing practices at the national and subnational levels

- Attitudes, beliefs and practices of tobacco farmers, their historical and cultural context

- Occupational health hazards related to cultivating, curing, and handling tobacco

- Tobacco products as an international and regional trade issue, in terms of foreign exchange earnings, employment, trade, and trafficking

- Organisation, ownership, and regulation of the tobacco industry, both state owned companies and TTCs

- Market and economic relations within the tobacco industry, including the relative market share of state owned tobacco companies

TTCs, Transnational tobacco companies

(4) A need for concerted mobilisation of human and financial resources in order to implement a comprehensive research agenda, build partnerships and stimulate comparative research and analysis.

\section{SPECIFIC RESEARCH ISSUES}

Most of the specific research issues were descriptive in nature and related mainly to the supply side (table 1 ).

In addition, there was an interest in doing more detailed and analytical studies both on the supply and demand sides. These are summarised in table 2 .

DIVERGENCES IN EMPHASIS AND APPROACHES Commonalities notwithstanding, there were evident differences between the three regions in terms of emphasis and approaches to research and capacity building. Specifically, there was a greater preoccupation in the African meeting with documenting who profits most from tobacco production, trade and manufacturing, and how much of those profits remain in the country and with the farmers themselves. In Latin America, the participants focused on epidemiological issues, including the paucity of baseline consumption and burden-of-disease data, and the behavioural aspects of tobacco use. The Asian and African

Table 2 Detailed analytical studies

\begin{tabular}{|c|c|c|}
\hline Tobacco use & Production and marketing & Taxation \\
\hline $\begin{array}{l}\text { Determinants of tobacco use, including } \\
\text { sociocultural and psychological influences } \\
\text { and their impact on high risk populations }\end{array}$ & $\begin{array}{l}\text { Individual, national and regional } \\
\text { dependence on tobacco }\end{array}$ & $\begin{array}{l}\text { Revenue and product loss as a result of } \\
\text { smuggling }\end{array}$ \\
\hline $\begin{array}{l}\text { Optimal components of a tobacco control } \\
\text { strategy (programmes and policies) }\end{array}$ & $\begin{array}{l}\text { Impact of growing presence of TTCs } \\
\text { in the region }\end{array}$ & $\begin{array}{l}\text { Barriers to and opportunities for regional } \\
\text { harmonisation of taxes and prices }\end{array}$ \\
\hline $\begin{array}{l}\text { Opportunities for and barriers to tobacco } \\
\text { control }\end{array}$ & $\begin{array}{l}\text { Changes in public perception of } \\
\text { advertising and promotion by TTCs }\end{array}$ & $\begin{array}{l}\text { Demand and supply elasticity studies for } \\
\text { an optimal level of taxation }\end{array}$ \\
\hline Influence of smuggling on tobacco use & $\begin{array}{l}\text { Dimensions and effects of brand } \\
\text { stretching }\end{array}$ & $\begin{array}{l}\text { Country and segment specific impact of } \\
\text { taxation on tobacco control }\end{array}$ \\
\hline $\begin{array}{l}\text { Influence of advertising and sponsorship } \\
\text { on tobacco use, particularly with respect } \\
\text { to women and children }\end{array}$ & $\begin{array}{l}\text { Impact of tobacco control legislation } \\
\text { and measures on cross border } \\
\text { marketing }\end{array}$ & \\
\hline \multirow[t]{4}{*}{$\begin{array}{l}\text { Effective messages to counter tobacco } \\
\text { promotion }\end{array}$} & $\begin{array}{l}\text { Tobacco production and destruction of } \\
\text { the ecosystem }\end{array}$ & \\
\hline & $\begin{array}{l}\text { Illegal trafficking: impact and } \\
\text { determinants }\end{array}$ & \\
\hline & $\begin{array}{l}\text { Crop substitution as a disincentive to } \\
\text { growing tobacco }\end{array}$ & \\
\hline & $\begin{array}{l}\text { Effect of international trade agreements } \\
\text { on production, trade, and marketing }\end{array}$ & \\
\hline
\end{tabular}


delegates, on the other hand, were more concerned about the influence of advertising and endorsement, and how to curtail them while they are still embryonic. Trafficking came up repeatedly in Latin America and in Africa. Asian representatives also discussed an extensive taxonomy of those involved in the chain of supply; the inter-relationships between and impact of each sector; and the behavioural determinants of tobacco use.

For Latin Americans, health education was predominantly a question of programme content. The Asian and African meetings discussed in detail: target groups; agents of change; the optimal mix of strategies in a comprehensive programme; the effectiveness of each component; methods and means of communication; and underlying behavioural models.

In discussing research on tobacco control policy, the Latin American meeting clearly elaborated the need to look at all types of legislation with respect to tobacco: economic, agricultural and environmental policies, as well as health policies. The Asian and African meetings focused on: who the players should be; the attitudes of policymakers and how to influence them; and how to empower not only decision-makers, but also policymakers, opinion leaders, religious leaders and women.

In discussing emerging issues, participants at all three meetings expressed a need to harmonise taxes and prices across each region. Latin American delegates reiterated the need for a regional surveillance system to collect data on cross border TTC strategies. Asian delegates discussed the impact of international trade agreements and the contribution of tobacco to the economy of the region. They also examined the changing nature of advertising and product mix in the context of increasing purchasing power and levels of education and urbanisation. The African meeting identified policy instruments (duties, subsidies, advertising and marketing controls), as well as policing and enforcement of policies. Also highlighted were trade issues, including regulation versus liberalisation of trade, and the impact of loss of government controls; building and strengthening regional research capacity; and capacity for litigation, all in the context of the South African Development Community.

With respect to overall approaches, Latin America differed in perceiving research as a somewhat separate endeavour in its own right. In Asia and Africa, on the other hand, there was some reluctance to think of research as separate from advocacy and tobacco control measures. In Asia, there was genuine interest in collaborative work, albeit along the traditional dividing lines of South and Southeast Asia. The Latin American participants showed somewhat less interest in intercountry collaboration, despite the cultural similarities within the region. In Africa, the participants advocated a more equitable partnership in terms of access to funding and capacity building across the region.

\section{Discussion}

Given the scarcity of funds available for tobacco control research globally, it is imperative that donors and the research community help to develop and agree on research priorities that will have the largest impact on populations and vulnerable groups in the developing world. Several attempts have been made to define priorities for research to curtail tobacco use and prevent or limit the burden of illness that it causes. The working group that was convened at the 10th World Conference on Tobacco or Health in Beijing came up with the following five recommendations: that the practices of the tobacco industry be investigated; that the proper mix of policies be identified through research; that transnational factors in tobacco use be studied; that a balance between research needs in terms of prevention and cessation be found; and that national level research be complemented by both subnational and international research. ${ }^{12}$ They further agreed that multidisciplinary research is key to effective interventions and policies. Their report called on the donor community and United Nations agencies to increase their funding and support to tobacco control research, and find ways and means for an effective partnership.

In a second attempt, an international committee of 13 members representing a broad expertise in the prevention and control of cardiovascular diseases was convened by the Institute of Medicine (IOM) of the US Academy of Sciences to prepare a report on cardiovascular diseases in developing countries. Their report, published by the IOM, also recommends five research subjects to reduce tobacco use. ${ }^{13}$ These are: prevalence studies of tobacco use in developing countries; time series to monitor tobacco consumption trends, especially in segments of populations most at risk such as children, adolescents and women; evaluative studies to determine the cost effectiveness of community based interventions to prevent smoking and of tobacco cessation programmes; and economic studies to estimate the total impact of tobacco production and consumption in a developing country context.

The regional workshops convened by RITC in Latin America, Asia, and Africa largely concurred with the two previous attempts at setting a research agenda for tobacco control, especially with regard to issues identified under the rubric of consumption.

The first of these was to improve knowledge of the size and nature of the tobacco related burden of disease in developing countries. All three regions expressed a need to develop regional surveillance systems that would provide baseline data and ongoing monitoring of patterns of morbidity and mortality associated with tobacco use.

The second was to establish the levels, determinants, and consequences of tobacco use. The most frequently stated research need at all three regional meetings was the need for data collection related to the prevalence of tobacco use and consumption patterns at the local, national, and regional level. The need to 
Table 3 Areas of convergence: recommendations of three agenda setting meetings

\begin{tabular}{|c|c|c|c|}
\hline Areas of convergence & $\begin{array}{l}\text { 10th Word Conference on Tobacco } \\
\text { or Health }\end{array}$ & $I O M$ & RITC \\
\hline $\begin{array}{l}\text { Improve knowledge of the size } \\
\text { and nature of the tobacco } \\
\text { related burden of disease in } \\
\text { developing countries }\end{array}$ & $\begin{array}{l}\text { Put in place a surveillance } \\
\text { strategy to track progress in } \\
\text { controlling tobacco use and } \\
\text { tobacco related disease. }\end{array}$ & $\begin{array}{l}\text { Estimate the total impact of } \\
\text { tobacco production and } \\
\text { consumption in a } \\
\text { developing country } \\
\text { context. }\end{array}$ & $\begin{array}{l}\text { Establish regional surveillance } \\
\text { systems to provide baseline } \\
\text { data on patterns and trends } \\
\text { in tobacco-attributable } \\
\text { morbidity and mortality. }\end{array}$ \\
\hline $\begin{array}{l}\text { Establish the levels, } \\
\text { determinants, and } \\
\text { consequences of tobacco use } \\
\text { at the local, national, and } \\
\text { regional level }\end{array}$ & $\begin{array}{l}\text { Track progress in controlling } \\
\text { tobacco use; investigate the } \\
\text { practices of the tobacco } \\
\text { industry; study transnational } \\
\text { factors in tobacco use; } \\
\text { complement national with } \\
\text { subnational and international } \\
\text { research }\end{array}$ & $\begin{array}{l}\text { Study the prevalence of } \\
\text { tobacco use in developing } \\
\text { countries; monitor tobacco } \\
\text { consumption trends, } \\
\text { especially in children, } \\
\text { adolescents, and women }\end{array}$ & $\begin{array}{l}\text { Establish regional surveillance } \\
\text { systems to provide baseline } \\
\text { data on the prevalence of } \\
\text { tobacco use and } \\
\text { consumption patterns and } \\
\text { trends }\end{array}$ \\
\hline $\begin{array}{l}\text { Document and assess the } \\
\text { impact of policies related to } \\
\text { tobacco use, including } \\
\text { health, economic, } \\
\text { agricultural, environmental, } \\
\text { and international trade } \\
\text { policies }\end{array}$ & $\begin{array}{l}\text { Identify the proper mix of } \\
\text { policies through research; } \\
\text { find a balance between } \\
\text { research on prevention and } \\
\text { cessation }\end{array}$ & $\begin{array}{l}\text { Determine the cost } \\
\text { effectiveness of community } \\
\text { based prevention and } \\
\text { cessation programmes }\end{array}$ & $\begin{array}{l}\text { Document and assess existing } \\
\text { policies and programmes }\end{array}$ \\
\hline $\begin{array}{l}\text { Build capacity for research } \\
\text { and establish a network for } \\
\text { communicating information, } \\
\text { data, and best practices }\end{array}$ & $\begin{array}{l}\text { Remedy the lack of a data } \\
\text { gathering infrastructure, } \\
\text { expertise and funding for } \\
\text { tobacco control research; } \\
\text { multidisciplinary research is } \\
\text { key to effective interventions } \\
\text { and policies }\end{array}$ & $\begin{array}{l}\text { Train investigators and } \\
\text { strengthen links between } \\
\text { basic, epidemiological, } \\
\text { clinical, and policy } \\
\text { research; foster a problem } \\
\text { solving, multidisciplinary } \\
\text { approach }\end{array}$ & $\begin{array}{l}\text { Identify stakeholders, } \\
\text { researchers and research } \\
\text { institutions and their needs; } \\
\text { build capacity for tobacco } \\
\text { control research, especially } \\
\text { in non-health related areas; } \\
\text { establish networks to } \\
\text { facilitate information } \\
\text { sharing, capacity building, } \\
\text { and the development of } \\
\text { multidisciplinary research } \\
\text { teams }\end{array}$ \\
\hline
\end{tabular}

IOM, Institute of Medicine; RITC, Research for International Tobacco Control.

identify the determinants of tobacco use and non-use, as well as those groups most at risk, and to describe the nature of underlying peer pressure was also stated.

The third was related to public health interventions. The regional meetings hosted by RITC were specifically designed to emphasise the role of policy based research. All three regions expressed a desire to document and assess the impact of policies that relate to tobacco use, including health, economic, agricultural, environmental, and international trade policies. All three groups took the opportunity to brainstorm about the optimal composition of a comprehensive national tobacco control strategy, developing extensive "wish lists" for programmes, policies, and evaluation. They discussed the role of different factors in a comprehensive strategy and which sectors should be involved in developing and implementing such a strategy.

The RITC meetings and the two previous agenda setting meetings also agreed on the importance of capacity building and information sharing. The working group convened during the 10th World Conference on Tobacco or Health noted that lack of expertise in tobacco control and even basic data collection left many developing countries vulnerable to aggressive market penetration by multinational tobacco corporations. ${ }^{12}$ The IOM committee identified the need to train investigators, and strengthen links between basic, epidemiological, clinical, and policy research in order to foster a problem-solving, multidisciplinary approach. ${ }^{13}$ The participants in the three regional RITC meetings not only recog- nised the need to build capacity for tobacco control research, they also began taking steps to do so. All three regions are preparing proposals to submit to RITC for the establishment of networks to facilitate information sharing, capacity building, and the development of multidisciplinary local, national or regional research teams (table 3 ).

Moreover, in spite of major similarities between the recommendations made in the three attempts to set a research agenda, the process adopted by RITC emerged as unique.

- First, by design and by virtue of the mix of participants, the RITC meetings and resulting agenda were more multidisciplinary and went beyond the field of health and health care research.

- Second, the regional workshops went further in their attempt to set research agendas by identifying a number of issues on the supply side that are directly related to the larger development context.

- Third, because of the more participatory and inclusive process followed in the regional workshops, researchers in the south are more likely to buy into these regional agendas.

The magnitude of the tobacco epidemic dictates that tobacco control research must be a significant component of the global health research agenda. The participation of stakeholders from developing countries at the regional meetings sponsored by RITC ensured 


\section{Appendix: list of participants of three regional meetings}

SETTING TOBACCO CONTROL RESEARCH PRIORITIES FOR EAST, CENTRAL AND SOUTHERN AFRICA REGION, JULIASDALE, ZIMBABWE, 11-13 JANUARY 1999

- Kenya: Mr Pamphil Kweyuh, Africa Tobacco Media Programme (ATOM); Mr Winston Ngaira, Waruhiu and Muite Advocates; Professor William Lore, Institute of Health Research and Services

- Lesotho: Dr M Mokheti, Ministry of Health

- Malawi: Mr Paul Kwengwere, Malawi Investment Promotion Agency; Mr Wilson Mandala, Agricultural Research and Extension Trust (ARET)

- South Africa: Dr Yussuf Saloojee, National Council Against Smoking; Dr Krisela Steyn, South African Medical Research Council; Ms Nicola Christofides, Women's Health Project

- Swaziland: Dr Steven Shongwe, Ministry of Health and Social Welfare; Mr David Pritchard, National Council of Smoking, Alcohol and Drug Dependence (COSAD)

- Ugnada: Dr Edward Kanyesigye, Medical Research Council Programme in Uganda

- Zimbabwe: Dr Stephen K Chandiwana, Blair Research Institute; Mrs Dorothy Dhliwayo, World Health Organization; Dr Saleem Farag; International Commission for Prevention of Alcoholism and Drug Dependency; Mr Garikai A Mangwiro, Ministry of Health and Child Welfare; Ms Shungu Mtero, Blair Research Institute; Dr Timothy J Stamps, Ministry of Health and Child Welfare; Mr S Tsoka, Ministry of Health and Child Welfare; Mr Lardja Sanwogou, Tobacco Free Intitiative, WHO

Observers

- Brazil: Dr Vera Luiza da Costa e Silva, Cancer Surveillance and Prevention Coordination INCA, Ministry of Health

- Canada: Dr Enis Baris, Research for International Tobacco Control; Ms Joanne Prindiville, Research for International Tobacco Control

- South Africa: Mr Wardie Leppan, International Development Research Centre; Mr Dominic Schofield, International Development Research Centre

- Sweden: Mr Paul Nordgren, National Institute of Public Health

- Thailand: Dr Hatai Chitanondh, Thailand Health Promotion Institute

- USA: Mr Robert Robinson, Centers for Disease Control and Prevention, Office on Smoking and Health

SETTING TOBACCO CONTROL RESEARCH PRIORITIES FOR LATIN AMERICA AND THE CARIBBEAN, RIO DE JANEIRO 17-19 AUGUST 1998

- Argentina: Dr Mirta A. Molinari, Unión Antitabáquica Argentina

- Brazil: Dr Elizabeth Moreira, National School Public Health-Ministry of Health; Dr Vera Luiza da Costa e Silva, INCA/Ministry of Health; Francisco José Roma Paumgarten, National School of Public Health-ENSP/FIOCRUZ_-Ministry of Health; Dr Luisa M da Costa e Silva Goldfarb, Contapp/ INCA-Ministry of Health; Dr Zulmira Hartz, National School of Public Health-ENSP FIOCRUZ - Ministry of Health; Dr Virginia Elizabeta Etges, Univ. Sta. Cruz Sul

- Colombia: Dr Margarita Ronderos, Ministerio de Salud

- Venezuela: Dr Celia Riera Betancourt, Consultant OPS/OMS; Dr Jorge A Osorio, National Anti-smoking Committee of Venezuela; Dr Natasha Herrera, PAHO consultant/Inter-agency Plan on Tobacco or Health

Observers

- Canada: Dr Enis Baris, Research for International Tobacco Control; Ms Eyra Edington, International Development Research Centre; Dr Rohinton P Medhora, International Development Research Centre; Mr Ian Stein, Canadian Public Health Association

- Thailand: Dr Hatai Chitanondh, Thailand Health Promotion Institute

- Uruguay: Dr Roberto Bazzani, International Development Research Centre

- USA: Dr Enrique Madrigal, Division of Health Promotion and Protection/PAHO/WHO

SETTING TOBACCO CONTROL RESEARCH PRIORITIES FOR ASIA, PATTAYA, THAILAND, 11-13 NOVEMBER 1998

- Cambodia: Dr (Mrs) Ouk Sokun, Ministry of Health, Dr Pun Sok, ADRA Cambodia

- China: Professor Wang Zhi-jin, Sun Yat-sen University of Medical Sciences

- India: Dr Atul Sarma, Indian Statistical Institute (Delhi Centre); Dr Prakash Gupta, Tata Institute of Fundamental Research; Professor PR Panchamukhi, Centre for Multidisciplinary Development Research

- Indonesia: Dr Soewarta Kosen, Ministry of Health; Ms Aditia Tutuarima

- Laos: Dr Bounsong Douangpraseuth, Ministry of Health

- Malaysia: Dr Rosemawati Ariffin, Ministry of Health

- Myanmar: Dr Than Swe, Ministry of Public Health

- Thailand; Dr Hatai Chitanondh, Thailand Health Promotion Institute; Dr Stephen L Hamann, Rangsit University School of Medicine; Dr Varabhorn Bhumiswasdi, Ministry of Public Health; Dr Supakorn Buasai, Health Systems Research Institute; Dr Naowarut Charoenca, Mahidol University

- Vietnam: Dr Nguyen Ngoc Khang, Ministry of Health; Dr Dang Hung Tuan, The National Cancer Institute

Observers

- Canada: Dr Enis Baris, Research for International Tobacco Control; Ms Linda Waverley Brigden, Research for International Tobacco Control; Dr Rohinton Medhora, International Development Research Centre; Mrs Caroline Pestieau, International Development Research Centre

- Turkey: Professor Gül Turan, Istanbul University; Professor Nazmi Bilir, Hacettepe University

- Zimbabwe: Ms Shungu Mtero, Blair Research Institute 
that a broad range of issues relevant to each area was considered. As a result of their involvement in setting research priorities, researchers in the three regions are anxious to initiate projects that will address them. As tobacco control takes its rightful place on the global health agenda, it is important that funding for tobacco control research be increased. Significant gaps in information have been identified at the regional meetings. These data are urgently needed to provide a sound basis for the development of policies and programmes to curtail the devastation brought about by tobacco. In this respect, as well as supporting the development of regional networks and policy relevant research in the south, RITC is prepared to work with others to advocate for global tobacco control research.

The authors gratefully acknowledge the assistance provided by Ms Rosemary Kennedy, Coordinator, RITC, in the preparation of this manuscript, as well as the valuable contribution made by staff members at the National Cancer Institute in Rio de aneiro, Brazil, the Thailand Health Promotion Institute in Bangkok, Thailand, and the Biomedical Research and Training
Institute in Harare, Zimbabwe in the planning and execution of Institute in Harare, Zim
the regional meetings.

1 Murray CJL, Lopez AD. The global burden of disease: a comprehensive assessment of mortality and disability from diseases, injuries, and risk factors in 1990 and projected to 2020. Boston: Harvard University Press, 1996.
2 Yang G, Fan L, Tan J, et al. Smoking in China: findings of the 1996 national prevalence survey. $7 A M A$ 1999; 282:1247-53

3 MacKay J, Crofton J. Tobacco and the developing world. In: Doll R, Crofton J, eds. Tobacco and health. London: Royal Society of Medicine Press, 1996:206-21.

4 Geist HJ. Global assessment of deforestation related to tobacco farming. Tobacco Control 1999;8:18-28.

5 Muwanga-Bayego $\mathrm{H}$. Tobacco growing in Uganda: the environment and women pay the price. Tobacco Control ronment and

6 The World Bank. Curbing the epidemic: governments and the economics of tobacco control. Washington, DC: The World Bank, 1999.

7 Cunningham R. Smoke and mirrors: the Canadian tobacco war. Ottawa: International Development Research Centre, 1996.

8 Abedian I, van der Merwe R, Wilkins N, Jha P, eds. The economics of tobacco control: towards an optimal policy mix. Cape Town: Applied Fiscal Research Centre, University of Cape Town, 1998.

9 Ritthiphakdee BO. Tobacco control in Thailand: vigilance and diligence. Bulletin Medicus Mundi 1999;72:17-21.

10 Hsieh C-R, Hu T-W, Lin C-FJ. The demand for cigarettes in Taiwan: domestic versus imported cigarettes. Contemporary Economic Policy April 1999;17:223-34.

11 World Health Organization. Investing in health research and development: report of the ad hoc committee on health research relating to future intervention options. Geneva: WHO, 1996.

12 Samet JM, Yach D, Taylor C, et al. Research for effective global tobacco control in the 21 st century: report of a working group convened during the 10 th world conference on tobacco or health. Tobacco Control 1998;7:72-7.

13 Howson CP, Reddy KS, Ryan TJ, et al. Control of cardiovascular diseases in developing countries: research, development, and institutional strengthening. Washington, DC: National Academy Press, 1998. 